Libre des Sciences Politiques. After graduating, he worked for three years as a foreign correspondent for Agence Telegraph-Orient. When France fell, Frank made his way out of Europe through Spain and arrived in the United States in December 1941.

After working in a war plant in Buffalo for a year, Frank served in the U.S. Army from 1942 to 1946 , receiving U.S. citizenship in March 1943. Following the war, he went to graduate school at the University of California, Berkeley, where he received his Ph.D. in political science in 1954 for a pioneering dissertation on political values. He spent a year at the Center for Advanced Studies in the Behavioral Sciences before joining the department of political science at Michigan State University as an instructor in 1955 . He rose through the ranks to become professor in 1965 and retired in 1981.

In 1959, with colleagues Paul Jacobs and Philip Selznick, Frank wrote Old Age and Political Behavior, a study of the California Institute of Social Welfare and of its leader, George H. McLain. An early exemplar of behavioral research in the discipline, and an important study in its own right, the book contained data collected from questionnaires sent to a systematic sample of the group's 70,000-plus members, content analyses of McLain's daily radio broadcasts, and examination of files and correspondence of the organization. The authors found the psychological needs of elderly pensioners to be an important component of the group's appeal and of the relationship between McLain and his followers.

Throughout the 1960s, Frank devoted much of his attention to studying student political activism and issues in secondary education. He wrote several important analyses of student movements, including "Student Trade-Unionism in France, Belgium and Holland: Anticipatory Socialization and Role-Seeking" for Sociology of Education (Spring 1964); "Parental Overprotection and Political Distrust" for Annals of the American Academy of Political and Social Science (September 1965); "Tradition and Transgression: West- ern European Students in the Postwar World" for Daedalus (Winter 1968); and "Students: A Marginal Elite in Politics" for Annals of the American Academy of Political and Social Science (May 1971). In 1966, he wrote Relationships Between High School Group Structures and the Development of Orientations Toward Public Affairs, for which he developed numerous instruments for measuring high school students' social context and political attitudes. Frank's interest in education was also evidenced by his coauthoring of Decision Making on the Reform of Educational Finances in Michigan: A Report to the Urban Institute in 1971 with John N. Collins and William A. Sederburg. In fall 1966, Frank taught at the Institute for Advanced Studies in Vienna.

Frank's principal interests lay in political behavior research, especially in political psychology and political socialization, and this led him to play a crucial role in the development of graduate training in both empirical methods of political research and political psychology at Michigan State University. He served as the original director of the Bureau of Social and Political Research at MSU, which in addition to sponsoring research on political processes was also a center for graduate training in research methods.

An active member of the department, Frank was extremely generous with his advice to both students and colleagues; we all benefitted from his insights into political and psychological processes early in our careers at Michigan State. He could be brutally honest but was usually right on target. He was also a good citizen of the larger world, active in many political causes and an important member of the liberal political community in East Lansing. Frank was an eternal optimist, interested in everything, full of vitality, and always planning for his project. $\mathrm{He}$ exemplified a generation that endured much but contributed greatly.

Frank's marriage to Virginia Hitchcock ended in 1981 but, still full of enthusiasm and vitality, he married for a second time at age 80 and subsequently moved to East Falmouth, Massachusetts. There, he gave himself over to his long-time hobby of woodworking and cabinetry and partially built the interior of a new home in a cooperative community. He died on October 28, 1999, and is survived by his widow, Dorothy Carlock, and his two daughters from his first marriage, Bepi Pinner of North Carolina and Karen Parsell of Ohio. He spent his last months in North Carolina, where he was cared for by Bepi. In his later years in East Lansing, Frank joined the Unitarian Universalist Church of Greater Lansing, where he met his second wife, made many close friends, and was very active in church programs and activities. A touching memorial service was held for him there on February 19, 2000.

Contributions in Frank's memory may be made to the Lansing branch of the American Civil Liberties Union.

Paul R. Abramson Michigan State University Ada W. Finifter Michigan State University

\section{William B. Prendergast}

William Broderick Prendergast, 85 , died of heart failure at his home in McLean, Virginia, on December 7, 1999. During a long and varied career, he,was, at various times, a political science professor, political consultant, lobbyist, candidate, and author. At the height of his career, from the late 1950 s to the mid1960 s, he served as director of research for the Republican National Committee and later for the Republican Conference of the House of Representatives. Theodore White, in one of his classic books on presidential campaigns, noted that Prendergast ran the best research operation in Washington.

During the 1950s and 1960s, the national and congressional party committees still played an important role in national politics. They still had campaign responsibilities and were relied upon by state and local candidates to provide campaign and candidate research. They raised money, planned campaigns, and advised candidates, all activities that have now largely been assumed by political consultants. Bill Prender- 
gast's series of election studies were among the best compilations of aggregate election data available at the time and were widely admired and utilized by political scientists and journalists. He also provided staff research assistance in the drafting of the national party platforms throughout the 1960s.

Bill Pendergast graduated from the University of Notre Dame, where he received his bachelor's and master's degrees in political science. He also received a licentiate in political science from the University of Louvain in Belgium prior to completing his doctorate in political science at the University of Chicago. He taught political science and history at the U.S. Naval Academy from 1946 to 1956 and also taught courses in government and international relations at Catholic University and Johns Hopkins University.

A native of Bridgeport, Connecticut, Prendergast arrived in the Washington area after serving in the Army and the Office of Strategic Services during World War II. He was discharged as a captain. In 1956, he fulfilled a lifelong dream by running for Congress from Maryland, albeit unsuccessfully.

After the election of President Richard Nixon in 1968, Bill Prendergast was named a special assistant to the secretary of defense; three years later he was named defense advisor to the U.S. mission to NATO in Brussels, Belgium. He worked for the ACTION program of the Office of Economic Opportunity until 1976. Subsequently, he was a consultant and lobbyist for a number of trade groups.

During his long career, he produced many notable research monographs for the Republican party organizations he served. He published a number of articles on politics for Commonweal, America, and American Political Science Review and he wrote for several organizations, including the American Enterprise Institute. One of his proudest achievements was publishing The Catholic Voter in American Politics in June, just a few months before his death.

He was a member of St. John's Catholic Church in McLean, the Capitol Hill Club, the Notre Dame Club of Washington, the American Political Science Association, the American Catholic Historical Asso- ciation, and the Eisenhower World Affairs Institute.

Bill Prendergast pioneered the use of statistics for policy research, and was a master at presenting results in such a way as to make them understandable to average citizens, candidates, campaign managers, and journalists. He was widely admired in political circles and, at one point, officers of the Democratic National Committee successfully sought his advice and assistance in focusing and strengthening their own research efforts.

Those of us who knew and worked with Bill Prendergast during his years in Washington were always struck by the breadth of his knowledge of politics and his ability to apply it. During campaign periods, he was often on the telephone for entire days at a time answering questions and explaining results. $\mathrm{He}$ was generous with his knowledge and believed that the results of research, even research done under party auspices, should be made available and disseminated to those who needed it.

Bill Prendergast is survived by his wife of 57 years, Mary, two sons, one daughter, and eleven grandchildren.

Robert J. Huckshorn Florida Atlantic University

\section{Peter Snow}

Peter Snow died on November 16, 1999. For more than 30 years, he served on the faculty of the University of Iowa, having been recruited in 1962, the year before he completed his Ph.D. at the University of Virginia. Many who read this remembrance will already know of Peter's scholarship: the books on Latin American Radicalism, on political forces in Argentina, on charismatic bonding, and on Argentine government, in addition to the numerous published research papers. However, few readers will know much about his life, so that will be our focus.

Peter was born in Boulder, Colorado, in 1933. Years later he began his collegiate studies-though, as he would be the first to admit, "studies" is probably the wrong word-in that same community. Sampling the many delights of college life left Pe- ter little time to attend to such incidentals as attending classes and writing term papers. Soon, as it often did in the 1950s, the Army beckoned, and Peter served his country for two years in Austria before returning to college, this time at Texas Tech, with a new sense of academic purpose. He received his B.A. and M.A. in political science from Tech before moving to Virginia to pursue doctoral studies in Latin American politics.

At Iowa, Peter moved very quickly through the academic ranks, becoming a full professor only seven years after completing his Ph.D. While traveling along his professional path (indeed, throughout his entire life) he displayed a striking degree of self-reliance. After deciding in the late 1960s that he needed to know some statistics, he taught himself the subject up through the intermediate level, publishing an innovative paper on the application of cumulative scaling to measures of political development. When using computer applications to process data became standard practice among younger scholars, Peter taught himself how to program in FORTRAN and then wrote a program to do regression analysis. Of course, he quickly brought his new knowledge to bear upon his research and earned a welldeserved reputation for methodological innovation in Latin American political studies.

Peter held a lifelong devotion to baseball and believed the Brooklyn Dodgers to be the greatest actualization of the sport's mythic promise. He was himself a semi-professional pitcher before he found his way into graduate studies. In addition, Peter was a phenomenal poker player, as Iowa graduate students and faculty from the 1960 s will remember. He won so routinely in games with these innocents (who were also his friends) that, after a time, he concluded he could no longer continue taking their money in good conscience. So, except for games played against casino professionals, he set poker aside and turned his talents to creating crossword puzzles. His puzzles soon began appearing in publications around the world, including The New York Times. On one occasion, the Times puzzle editor took the very rare step of soliciting Peter 